\title{
Regional Integration and Food Security in East Africa
}

\author{
Doreen Alusa
}

\begin{abstract}
1.0 Introduction
Providing adequate food for their population has been one of the major challenges for the five member states of the East African Community (EAC). In various parts of these countries, food security is precarious and hundreds of thousands in the region are dependant on food intervention for their daily food requirement needs. Although food insecurity in the region is often attributed to natural disasters such as recurrent droughts, inappropriate policies that have failed to address the region's problems within the context of an increasingly globalized economy have also contributed to lack of adequate food.
\end{abstract}

Globalization refers to the restructuring of production and consumption in terms of location, ownership and exchange such that international links and flows become more important (Michelmann et. al., 2001: 1-2). Within the context of agriculture, globalization is being driven, in part, by the process of international trade liberalization under the auspices of the World Trade Organization (WTO). The most contentious rule that has been formulated by WTO is the Agreement on Agriculture (AoA), which aims to level international agricultural trade by reversing a trend of agricultural protectionism in Western countries. (Gallagher, 2000: 41-52).

Current research shows that protectionist policies contribute to food insecurity in developing countries by causing an overproduction of farm products, which are often dumped on the world's markets. The outcome is a depression in world agricultural prices and the undermining of the purchasing power of unprotected farmers, most of who reside in developing countries (Tupy, 2004: 35).

In spite of this evidence, many of the WTO member states have failed to adhere to the rules laid out in the WTO-AoA. This has resulted in disillusionment, especially by the developing countries, about the role of the WTO and has raised the possibility of Regional Trade Agreements (RTAs) ${ }^{1}$ becoming the instrument of choice for countries as they seek to reduce trade barriers, encourage investment and improve transparency in the market for goods and services. The paper argues that joint formation and implementation of comprehensive agricultural policies and the allocation of resources towards improving the agricultural sector will not only enhance food security and enable countries in East Africa cope with the interminable trends of globalization, but also result in increased economic growth and a reduction on poverty levels. The impediments to the implementation of these policies are also discussed.

\footnotetext{
${ }^{1}$ The term RTA includes free trade areas and customs unions based on regional proximity as well as bilateral reciprocal agreements that link trade partners farther a field. The more general term Preferential Trade Agreements include nonreciprocal arrangements as well as free trade areas and customs union.
} 


\subsection{The State of Food Security in East Africa}

The Rome Declaration agreed at during the World Food Summit in 1996 states that:

Food security is achieved when all people, at all times, have physical and economic access to sufficient, safe and nutritious food to meet their dietary needs and food preferences for an active and healthy life. (FAO, 2004)

Within this declaration, two dimensions of food security are identified. The first describes food security as self-sufficiency. A country that is self-sufficient is one which produces all its domestic food requirements without need for imports. The second dimension describes food security as food availability. A country that has food availability meets its food deficit by importing food of acceptable quality from other producers' outside the country (FAO, 2004).

In East Africa, none of the countries meets the food requirements for their entire populations. One of the reasons for this is that agricultural production in the region is mostly rain-fed and suffers frequent disruptions of drought and floods. Because of this, the region has been unable to achieve food self-sufficiency and this in turn has affected food availability (Ogutu, 1999: 54).

In cases where food is available, some of those without food lack purchasing power because of the increased market price of food. Lack of purchasing power is largely experienced by the rural population, which depends on agriculture for both its income and food entitlement. According to evidence assembled by Mellor (1986), although there has been a tendency to generalize that economic growth reduces poverty, it is in fact the direct and indirect effects of agricultural growth that accounts for the largest percentage of poverty decline. Since agriculture accounts for a large share of the national incomes of all East African states, improving agricultural trade may result in the improvement of the purchasing power of a majority of the population in the region and this would in turn increase the level of food accessibility (Ogutu, 1999: 46).

\subsection{The impact of Globalization on Food Security in East Africa}

There is a large, but far from universal, consensus that a liberal international trading system is desirable. The key benefit of economic freedom is economic development. According to Friedman (1982), economic development can be accelerated if governments make legal structures efficient, licensing procedures easier and affordable, and put in place policies that are friendly to entrepreneurship rather than punitive strategies. Through economic freedom, the country turns its population into a resource by unleashing individual drive and initiatives. (Shikwati, 2004:16).

In East Africa, agriculture continues to be the major sector of the economy. It employs approximately 70 percent of the labor force and provides nearly all the food requirements for the region's population. The main feature of East Africa's agriculture is domination by small-scale farmers who account for 75 percent of the total agricultural production and 70 percent of marketed agricultural output. On average, small-scale farmers produce over 70 percent of maize, 65 percent of coffee, 50 percent of tea, 90 percent of Sugar, 80 percent of milk, 85 percent of fish and 70 percent of beef and 
related products. Production is carried out on small land holdings averaging 2-3 hectares mainly for both dairy and beef subsistence and commercial purposes. (Kinyua, 2004)

In view of the desired outcome of liberalization, and the fact that the majority of East Africans depend on agriculture for their economic needs, the governments of Kenya, Tanzania and Uganda have supported and explored various avenues aimed at liberalizing agricultural trade. All three states are members of the World Trade Organization (WTO), which is the key agent of international liberalization. On January 1, 1995, the WTO came into being replacing the contracting parties of the General Agreement on Tariffs and Trade (GATT) of 1947. The GATT's main role was to prohibit the use of quantitative import barriers and reduce import tariffs on manufactured goods to low levels.

The GATT also provided specific exceptions for agricultural products; however, discussions about agricultural policies were kept outside the GATT framework. Over time, agricultural trade policies evolved in ways that differed radically from those applied for manufactured goods. The changes were marked by a host of domestic and export subsidies including non-tariff barriers such as variable levies, minimum import prices, voluntary export restraints and quantitative import quotas. These policies have increasingly become a source of international friction. For example, many developed countries have used domestic agricultural subsidies to guarantee farmers an "adequate" income. These subsidies stimulate production far beyond the capacity that their domestic markets can absorb generating surpluses that are purchased and held by governments in developed countries. Some governments then use export subsidies to sell the resulting surpluses on world markets. The surpluses on world markets undercut the developing world's competition by depressing prices by up to 12 percent. It is these prices that undermine unprotected farmers from developing countries and make it impossible for their products to compete with those from the developed countries (Tupy, 2004: 35).

The WTO has attempted to arbitrate issues arising from production subsidies in developed countries by creating the Agreement on Agriculture (AoA). The tradeliberalizing impact of the WTO-AoA, at least in the short run, was expected to level international trade by increasing food prices in the international market. This increase was to benefit food-exporting countries, including the three East African states, because higher world food prices increase export revenues even when export volumes remain fairly stable. Thus, depending on the transmission effect of world prices, producer income and their food security could be boosted. (Gallegher, 2000: 45-46)

In spite of these attempts, the WTO has come under severe criticism for failing to achieve any of its primary goals and has been described as an institution that sustains the global capitalist order for the benefit of powerful states. (Chimni, 2006: 5-8) All agricultural trade negotiations presided over by the WTO including the Tokyo and Uruguay Rounds of multilateral trade, the Ministerial Meeting in Seattle and the Doha Round have ended up in disarray. (The Economist, July 8-14, 2006: 14-15). Defendants of the WTO argue that it is not an organization responsible for promoting international 
development. Its fundamental role is to provide a set of rules for firms wishing to enter into international transactions. It should therefore, not be relied upon as an institution through which developing countries can seek protection from exploitation through trade. (Kerr, 2001: 53)

Because of the recurring breakdown in trade negotiation talks among WTO member states and uncertainty about the ability of the WTO to control international trade, the East African countries have pursued two main strategies to reduce trade barriers, encourage investment and improve transparency in the market for goods and services. The first strategy is based on the establishment of Preferential Trade Agreements (PTAs). States within the region are members of two key PTAs. These are the United States' initiative African Growth and Opportunities Act (AGOA) and the Cotonu Agreement on Trade, Aid and Sustainable Development, which is the centerpiece of the European Unions (EU) relationship with the African, Caribbean and Pacific countries (ACP) (Josling, 2001: 83)

Although the PTAs are supposed to enhance trade between developed and developing countries, these special trade deals often discriminate against the latter's most competitive produce by using non-tariff barriers to thwart commercial activities created by other trade liberalization policies. For example, the AGOA excludes tobacco and peanuts from its agreement yet these produce form part of the industrial crops that are produced within the East African region. The EU often invokes stringent Sanitary and Phyto-sanitary (SPS) measures that regulate movement of products across international borders for the protection of public health and the environment from pests, diseases and contaminants. Some of these health and safety regulations are excessive, making it impossible for African states to take full advantage of the PTAs. (Tupy, 2004: 39-40) In the end, the non-tariff barriers impede on the purchasing power within the region and subsequently do little to contribute towards food security.

\subsection{A Critical Analysis of the East African Community's Food Security Policy}

It is often asserted that African states are by and large by-standers in the globalization process largely because of their fragmented, small and frail economies. (Idahosa, 2004: 98). In political discourse, it is argued that socio-economic progress in African states can be achieved if divisions are put aside in favor of a more homogeneous system. (Otieno, 1990: 50). In the twenty first century Regional Trade Agreements (RTAs) have been identified as the best bulwark against unfair trading policies for the African states. Through integration, African economies can address constraints of a limited market by increasing intra-African trade specialization and allowing African countries to benefit from this process. (Quashigah, 2001: 31)

The most concerted effort at regional cooperation in East Africa has been the EAC. The EAC brings together five countries, the Republic of Kenya, the Republic of Uganda, the United Republic of Tanzania, the Republic of Rwanda and the Republic of Burundi in a common endeavor to bring about accelerated and balanced development as well as an expansion of their economic activities (East African Community, A Handbook, 1972: 51; ipp media, 2006). The concept of the EAC can be traced through successive social and economic integration amongst them being the construction of the Kenya Ugandan 
Railway between 1897 and 1901, the creation of the East African Common Market in 1900, and the establishment of the East African Common Service Organization before it was replaced by the EAC in 1967. The EAC collapsed in 1977 and after several mediation agreements was fully revived in 1999 with the signing of the East African Community Treaty (EAC Secretariat Arusha, 1999).

In accordance with Articles 105, 106, 107, 108, 109 and 110 of the EAC Treaty ${ }^{2}$, food security is one of the important factors for the sustainability of the EAC. Available statistics show that the region can attain food self-sufficiency in almost all the food commodities and increase export capacity in several commodities if full liberalization of commodity markets is implemented. Trade is an important food instability buffer and an agent for food security because production variability and hence, price variance is lower at a regional rather than national level. However, the implementation of free market policies should also be accompanied with policies that counter risks that may lead to prices that erode the purchasing power of most households and expose them to reduced accessibility to food. (EAC Secretariat Arusha, 2004; 13)

The importance of the EAC is more crucial in the enhancement of food security in the region in light of the likely trajectory of globalization on food security. According to Thompson, (2001: 256) the long-term impact of globalization on agriculture will be the development of specialization as long-term barriers and disruptive mechanisms such as export subsidies are reduced or eliminated. This means that there will be fewer people farming even in successful farming areas, because expansion and enlargement of existing farm operations often means structural change, which displaces more labor than it generates. In farming areas unable to compete in the global markets, the changes will be more severe, and land transfers to other uses or simply abandonment must be contemplated. Indeed, it has been argued that the biggest beneficiaries of liberalization in agricultural products will be huge producers. Therefore, it makes a lot of economic sense if the East African states traded as a region rather than individual states so as to achieve food security and address the region's problems within the context of an increasingly globalized economy.

The EAC secretariat has laid out several policies for the improvement of intra-regional cooperation and investment coordination, while making sure that individual national policies do not affect the regional flow of food commodities. The policies generally include joint development projects for the improvement of infrastructure so as to reduce the extremely high marketing costs, common measures that will void and abolish the policy of export and import bans of food commodities and partnership in research and technology. (EAC Secretariat, Arusha, 2004: 37-58) In addition to the current policies, rural financial institutions should be strengthened to avail cheap and ready working capital to traders. It is also crucial for the EAC member states to establish, in areas where such systems do not exist, and to improve, in areas where they do exist, information systems and early warning systems on production trends and market situation to enable traders to make informed decisions and react appropriately to any impending shortages. (Ogutu, 1999: 71)

\footnotetext{
${ }^{2}$ See Appendices for details.
} 
In spite of the well laid out strategies for the improvement of food security in the region, most of the policies have not been implemented on grounds that they are still at the study stage. Although a thorough investigation of all policies is crucial for their success, the longevity of these studies can also be attributed to various factors that are prevalent in all three countries in the region.

First, the predominance of elitist politics in the integration efforts among the East African countries has stunted the implementation of policies by the EAC. Although food security is an economic issue that should be addressed technically, the ad hoc nature of interventions by some of the East African governments defeats the gains made through trade liberalization in the region. For instance, the reintroductions of subsidies and price supports have been suggested as alternatives to market liberalization in efforts to enhance food security in the region.

The proponents of protectionism argue that the new market system has failed to buffer producers and low-income consumers against severe production and price shocks. It is because of such views that some officials of the Kenyan government, in the late 1990s, clamored for the protection of maize producers in the Rift Valley. This occurred on a backdrop of maize deficit in other parts of the country and across the border in Tanzania. The prices offered in the deficit areas could adequately cover the transfer costs from any other part of the country yet the debate centered on the necessity for state funded subsidy rather than on a market, and especially cross-border, solution to a localized glut. The result was that consumer prices for maize became unaffordable to consumers experiencing drought conditions. (Ogutu, 1999: 58)

The above impediment is closely linked to preoccupation with production strategies inherited from the colonial period that have become obsolete in the twenty first century. These strategies include the traditional role of producing undifferentiated primary commodities for the domestic market. One of the most prevalent generalizations is that the most important commodity is maize. National food security strategies in development plans and Sessional Papers constantly refer to maize production as the most important aspect of food security. (Nyoro, Kirimi, Jayne, 2004) This has created a situation whereby a shortage of white maize spells hunger for the population. The promotion of maize has prompted producers to gradually abandon most of the traditional food crops (such as bananas, sweet potatoes, cow/traditional beans, cassava, millet, sorghum) that used to contribute to the food security of households.

According to Ogutu (1999: 50-61), it is crucial for this trend to be reversed by implementing a strategy for promoting nutritional diversity through appropriate policies such as allowing the market system to alter relative food prices in favor of maize alternatives. Tax breaks and duty waivers for imports of inputs are also needed to encourage non-conventional food production and processing.

Another colonial practice that impedes on the implementation of food security policies in the region is the tradition of seeking assistance from Western countries in times of crisis. Over the past several years, various parts of the East African region have experienced food deficits because of prolonged droughts. The key strategy that has 
always been pursued in drought prone areas is solicitation for large inflows of food aid from donors (Ogutu, 1999: 55). Although the massive food aid has contributed, without doubt, to saving lives and preventing thousands of people from starving, it has also crowded out foreign development and investment related capital and distorted production incentives to local producers. Donor dependency is already highly visible on the part of both national governments and rural farming communities prone to drought related food deficits. (United Nations Economic Commission for Africa, 1992: 52)

The East African countries are also upholding some of the economic paradigms that were pursued during the colonial period. After the Second World War, colonial states such as Britain introduced tariffs to protect their colonial markets against foreign competition. To date, the East African states remain faithful to some of the institutional practices imposed by the colonialists. These practices which include regulations and restrictions on banking, finance and capital markets reduce freedom and exchange and frustrate trade and commerce at the detriment of intra-regional trade and cooperation. (Shikwati, 2004: 14)

There is also fear by smaller economies, in the region, that they may be dominated by more industrialized member states should they fully yield to the terms of RTAs. This situation partly explains the dissatisfaction of Uganda and Tanzania with the EAC. The balance of trade within the region is currently in favor of Kenya. The former states provide Kenya with the biggest market for exports, which are largely, processed agricultural and industrial goods. (Ogutu, 1999: 62) In spite of the current trade imbalance among EAC member states, full implementation of agricultural policies must be pursued because according to studies of one of the most successful RTAs the EU, in the long run, it is actually the disadvantaged states that stand to be the greatest beneficiaries of RTAs. Within the EU, the greatest beneficiaries have not been the largest economies namely France and Germany but rather, tiny and remote countries including Luxembourg, Ireland, Portugal and Greece. This is because of the development of infrastructure that has facilitated intra-regional trade and the decision to concentrate resources, in the early years, on the development of the agricultural sector. (Pooley, 1999: 168-169)

\subsection{Conclusion}

The article attempted to investigate and asses the state of food security in East Africa. Studies reveal that although economies in the region are highly dependant on agriculture, none of the states have attained food security for their entire populations. While ecological reasons have been identified as some of the causes of food insecurity, the current trends in economic globalization are major contributing factors to food insecurity in the region.

The key challenge for respective East African governments has been the formulation and implementation of policies that would enable farmers to benefit from the liberalization of the international trade system. Several avenues that have been pursued in this regard include the WTO-AoA, PTAs with the United States and the EU as well 
as RTAs through the EAC. Of the three avenues, the EAC appears, for now, to offer the best strategies for achieving food security in the region.

In spite of the advantages that could be gained through the implementation of EAC policies, the execution of many of the policies have been delayed on grounds that they are still at the study stage. Although a thorough investigation of all policies is crucial for their success, the longevity of these studies can also be attributed to factors unrelated to the research processes such as political elitism, the existence of obsolete economic policies inherited from former colonial governments and concerns over issues related to balance of trade among member states. The paper recommends, based on the evidence presented, that the three East African states should wholeheartedly embark on regional integration as the surest impetus towards the achievement of food security in the region.

\subsection{References}

Ackello-Ogutu, C. (1999). "Prospects for trade in Agricultural Products within East African Co-operation Region," in Perspectives on Regional Integration and Co-operation East Africa, Arusha: EAC Secretariat.

Chimni, B. S. (2006). “The World Trade Organization, Development and Democracy: A View from the South," Journal of World Trade, 40(1): 5-36.

East African Community (EAC) (1999). Perspectives on Regional Integration and Cooperation in East Africa. Arusha: EAC Secretariat.

East African Community (EAC) (2004). Protocal for Sustainable Development of Lake Victoria Basin. Arusha: EAC Secretariat.

East African Community (EAC) (2004). Report of the Committee on Fast Tracking East African Federation, Submitted to the Sixth Summit of Heads of State of the East African Community. Arusha: EAC Secretariat.

East African Community (EAC) (1972). The East African Community, A Handbook. Arusha: EAC Secretariat.

Food and Agriculture Organization (FAO) (2004). The State of Food and Agriculture. Rome: FAO.

Friedman, Milton and Friedman, Rose (1982). Capitalism and Freedom. Michigan: Netlibrary incorporated.

Gallagher, P. (2000). Guide to the WTO and Developing Countries, London; Kluwer Law International. 
Harlow, J. (1997). Regional Cooperation and Integration with Industry and Trade in Southern Africa. Aldershot, UK: Averbury.

Idahosa, Paul L. Ehioze., (2004). "A Tale of Three Images: Globalization, Marginalization, and the Sovereignty of African Nation-States," in john Mukum Mbaku and Suresh Chandra Saxena, Eds., Africa at Crossroads: Between Regionalism and Globalization. Westport: Praeger.

International Food Policy Research Institute (IFPRI). (2004). Assuring Food and Nutrition Security in Africa by 2020 : Proceedings of an all-Africa Conference, Kampala, Uganda, April 1-3 2004 Washington, D.C : IFPRI

Josling, T., (2001). “Regional Trade Agreements and Agriculture: A Post-Seattle Assessment" in Michelmann, H. J., Rude, J., Stabler, J. and Storey, G. Eds., Globalization and Agriculture Trade Policy. Colorado: Lynne Rienner Publishers.

Kerr, W., (2001). "The World Trade Organization and the Environment," in Michelmann, H. J., Rude, J., Stabler, J. and Storey, G. Ed., Globalization and Agriculture Trade Policy. Colorado: Lynne Rienner Publishers.

Kinyua, J."Towards Achieving Food Security in Kenya," Assuring Food and Nutrition Security in Africa by 2020: Prioritizing Action, Strengthening Actors and Facilitating Partnerships, April 1-3 2004, Kampala, Uganda. Retrieved September 20, 2006, from http://www.ifpri.org/2020africaconference/program/day1summaries/ kinyua.pdf\#search $=\% 22$ food $\% 20$ security $\% 20$ in $\% 20$ kenya $\% 22$

Madley, J., (2000). Hungry for Trade: How the Poor Pay for Free Trade. Sydney: Pluto Press.

Mathews, (2003). Regional integration and Food Security in Developing Countries. Rome: FAO Retrieved September 20, 2006, from http://www.fao.org/docrep/004/y4793e/ y4793e00.htm.

Mellor, J. W., Ed. (1986). Agriculture on the Road to Industrialization. Baltimore: John Hopkins University Press.

Michelmann, H. J., Rude, J., Stabler, J. and Storey, G., (2001). “Introduction" in Michelmann, H. J., Rude, J., Stabler, J. and Storey, G. Eds., Globalization and Agriculture Trade Policy. Colorado: Lynne Rienner Publishers.

Moseley, G., and Ikubolajeh, L., (2005); "Food security" in Wisner, B., Toulmin C., and Chitiga, R., Eds., Towards a New Map of Africa. Vancouver: Earthscan.

Nyoro, J., Kirimi, L. and Jayne T.S. (2004). Competitiveness of Kenyan and Ugandan Maize Production: Challenges for the Future. Kenya: Tegemeo Institute of Agricultural Policy and Development, Egerton University. 
Otieno, J. W., (1990). “The Experience of the African Development Bank in Financing Regional integration Projects in Africa," in Anyang' Nyong'o, Ed., Regional Integration in Africa: Unfinished Agenda. Nairobi: Academy Science Publishers.

Pooley, P. (1999). “The European Union's Experience in Integration," in Perspectives on Regional Integration and Co-operation East Africa, Arusha: EAC Secretariat.

Shikwati, J. (2004). “The Prospects for Economic Freedom in Africa," in James Shikwati, editor, Reclaiming Africa, Nairobi: IREN.

The Economist, Trade Talks: Slouching Towards Disaster. July 8-14 2006, pp. 14-15.

Thompson, K. (2001). "Rural Policy" in Michelmann, H. J., Rude, J., Stabler, J. and Storey, G. Eds., Globalization and Agriculture Trade Policy. Colorado: Lynne Rienner Publishers.

Tupy, M., (2004). "Internal Barriers to Trade in the Developing World," in James Shikwati, J. Ed., Reclaiming Africa. Nairobi: IREN.

Shikwati, J., (2004). “The Prospects for Economic Freedom in Africa," in Shikwati, J. Ed., Reclaiming Africa. (Nairobi: IREN.

Quashigah, (2001). Opportunities for Growth in Food security in a changing Africa: Proceedings of the Workshop on Africa Food Security in a Changing Environment - Sharing Good Practices and Experiences. Kampala, Uganda, June 6-9.

United Nations Economic Commission for Africa (UNECA). (1992). “Food security in Africa" in Obasanjo O., Ed., The Challenges of Agricultural Production and Food Security in Africa. Washington, D.C : Crane Russak.

\section{Acronyms}

ACP African, Caribbean and Pacific countries

AGOA African Growth and Opportunities Act

AoA Agreement on Agriculture

EAC East African Community

EU European Unions

PTAs Preferential Trade Agreements

RTAs Trade Agreements

WTO Trade Organization 